\title{
AIDS-Related Gastric Kaposi Sarcoma
}

National Cancer Institute

\section{Source}

National Cancer Institute. AIDS-Related Gastric Kaposi Sarcoma. NCI Thesaurus. Code C5624.

A Kaposi sarcoma arising from the stomach in patients who are infected with the human immunodeficiency virus. 